\title{
Stream Structural Limitations on Invasive Communities in Urban Riparian Areas
}

\author{
Robert J. Warren II, Daniel L. Potts, and Kelly M. Frothingham*
}

\begin{abstract}
Urban riparian plant communities exist at the interface between terrestrial and aquatic habitats, and they are rich sources of species biodiversity and ecosystem services. The periodic floods that promote species diversity in riparian plant communities also increase their vulnerability to nonnative plant invasions. Plant invasions are constrained by seed and suitable habitat availability. However, how seed dispersal and establishment limitations interact to shape nonnative plant invasions in riparian communities is poorly understood. We use Stream Visual Assessment Protocol data to evaluate the hydrological and geomorphological parameters that influence the seeding and establishment of six common nonnative species in urban riparian habitats: garlic mustard, purple loosestrife, reed canarygrass, common reed, Japanese knotweed, and multiflora rose. To address this objective, we analyzed stream reach data collected during a basin-wide environmental assessment of the extensively urbanized upper Niagara River watershed. We found limited support for our prediction that propagule limitation constrains the distribution of nonnative riparian species, likely because these species are well established in the study area. Instead, we found that opportune stream reach characteristics better predict the distribution of the common invasive riparian species-most notably open tree canopy. Given that there is widespread investment in urban riparian forest restoration to improve water quality, increase stream-bank stability, enhance wildlife habitat and promote recreation, our data suggest that riparian forests may provide the additional benefit of reducing the abundance of some, but not all, invasive plants. Nomenclature: Garlic mustard, Alliaria petiolata (Bieb.) Cavara \& Grande; purple loosestrife, Lythrum salicaria L.; reed canarygrass, Phalaris arundinacea L.; common reed, Phragmites australis (Cav.) Trin. ex Steud.; Japanese knotweed, Polygonum cuspidatum Sieb. \& Zucc.; multiflora rose, Rosa multiflora Thunb. ex Murr.
\end{abstract}

Key words: Novel community, seed limitation, Stream Visual Assessment Protocol, suitable habitat.

Establishment (suitable habitat) and seed (propagule pressure) limitations control plant colonization (Clark et al. 2007; Warren et al. 2012). That is, plants need suitable local conditions and the ability to reach them for successful recruitment (seed germination and seedling survival). In turn, initial seed recruitment shapes plant communities (Albrecht and McCarthy 2009; Grubb 1977; Warren and Bradford 2011). Establishment and seed limitation are not independent, however, as continued or prodigious seed input can mitigate habitat limitations (Pulliam 1988; Warren et al. 2012). Generally, exotic invasive plants appear to have few habitat or propagule limitations so that they are able to colonize and persist across the landscape (Eschtruth and Battles 2009; Von Holle and Simberloff

DOI: $10.1614 /$ IPSM-D-14-00081.1

* First and second authors: Assistant Professor and Associate Professor, Department of Biology, SUNY Buffalo State, 1300 Elmwood Avenue, Buffalo, NY 14222; third author, Associate Professor, Department of Geography and Planning, SUNY Buffalo State, 1300 Elmwood Avenue, Buffalo, NY 14222. Corresponding author’s E-mail: hexastylis@gmail.com
2005; Warren et al. 2012, 2013). However, these plant invasions typically are associated with anthropogenic disturbance (Chytry et al. 2008; Elton 1958; King and Tschinkel 2008; Warren et al. 2011b), suggesting that establishment limitations remain important. Hence, evaluating species colonization requires investigation into the relative contributions of both establishment and seed limitations (Clark et al. 2007; Colautti et al. 2006; Lockwood et al. 2005; Parendes and Jones 2000; Poulsen et al. 2007; Tanentzap and Bazely 2009).

Exotic plant species colonize stream riparian habitats worldwide, particularly in human-altered and urbanized landscapes (Hood and Naiman 2000; Maskell et al. 2006; Parendes and Jones 2000; Pysek and Prach 1993). Riparian plant communities contain high species richness and, as the interface between land and water, they are an integral component of terrestrial and aquatic ecological and ecosystem processes (Cummins et al. 1989; Gregory et al. 1991; Groffman et al. 2003; Naiman et al. 1993; Sabo et al. 2005; Tickner et al. 2001); the influx of exotic invasive species alters their ecological and ecosystem functioning (Bradford et al. 2007; Hood and Naiman 


\section{Management Implications}

The progression from individual plant invasions to the establishment of widespread exotic communities requires that potential invaders are available and that there is suitable habitat in which they can establish. Nonnative riparian plant communities are widespread, particularly in urban areas, and often share common species. We evaluated the hydrologic and geomorphologic parameters that might influence the urban riparian distributions of six common nonnative riparian species in the urbanized upper Niagara River watershed: garlic mustard, purple loosestrife, reed canarygrass, common reed, Japanese knotweed, and multiflora rose. We found that four of these species are well established in the region so that seed availability did not appear limiting; instead, we found riparian canopy cover the strongest limiting factor on the invasive riparian communities. These data suggest that limiting the distribution of invasive species in urban riparian habitats requires a straightforward approach: restore riparian forests. Forest restoration in urban/ riparian habitats is a widespread management goal expected to create many ecological benefits, including improved habitat and water quality. Still, the stream-forest interface is inherently edge habitat, and invasive species thrive along forest edges. Increasing forest canopy may reduce invasive species communities, but the widespread presence of well-established riparian invaders and the mitigating effects of stream-bank edge habitat suggest that full eradication is unlikely. Moreover, we also found conflicting speciesspecific associations and habitat responses, suggesting that managing individual invasive species may require specific interventions.

2000; Lecerf et al. 2007; Pysek and Prach 1993; Tickner et al. 2001)

Hydrologic variability creates microhabitat variation for multiple plant life forms by generating heterogeneity in riparian soils and landforms (Baatrup-Pedersen et al. 2013; Casanova and Brock 2000; Yang et al. 2011). Flooding changes riparian geomorphology by eroding stream banks and depositing sediments, and variation in flooding also causes gradients in wetting across riparian soils with distance from stream (Greet et al. 2011; Kronvang et al. 2009; Naiman and Decamps 1997). The mosaic in riparian microhabitats results in the coexistence of multiple plant species in diverse riparian communities due to differences in germination and survival abilities (Cummins et al. 1989; Gregory et al. 1991; Groffman et al. 2003; Naiman et al. 1993; Sabo et al. 2005; Tickner et al. 2001; van Leeuwen et al. 2014; but see Baatrup-Pedersen et al. 2013). Moreover, in addition to creating multiple habitats, moderate, reoccurring floods may limit competitive exclusion by dominant riparian species (Boedeltje et al. 2004; Gurnell et al. 2008; Vogt et al. 2006). However, the hydrologic variability that promotes plant species richness in riparian habitats also appears to increase their susceptibility to species invasion (Hood and Naiman 2000; Pysek and Prach 1993).
Urbanization and associated human activities alter hydrologic variability by influencing the frequency and duration of both high and low flows, and by increasing the temperature and nutrient enrichment of waters (Auble et al. 1994; Decamps et al. 1988; Engstrom et al. 2009; Nilsson et al. 1991; Paul and Meyer 2001; Rood and Heinz-Milne 1989; Walsh et al. 2014). High flow disturbs existing vegetation, and low flow promotes droughttolerant upland species; both altered urban flow regimes allow the incursion of invasive riparian species (Groffman et al. 2003; Maskell et al. 2006; Pysek and Prach 1993).

In addition to shaping plant communities through flood disturbance and dynamic resource availability, streamflow often acts as the seed vector for those communities (Jansson et al. 2005; Merritt et al. 2010; Nilsson et al. 2010). Hydrochory (water dispersal) is a major source of propagule pressure for plants colonizing riparian habitats (Jansson et al. 2005; Leyer 2006; Merritt et al. 2010), dispersing seeds (or viable vegetative parts, e.g., Kowarik and Saumel 2008; Truscott et al. 2006) between riparian habitats at local and regional scales (Andersson et al. 2000; Gurnell et al. 2008; Jansson et al. 2005; Johansson et al. 1996; Merritt et al. 2010; Merritt and Wohl 2006; Vogt et al. 2006). Riparian plants often exhibit specific traits adapted to hydrochory, such as air cavities for increased floatation (Boedeltje et al. 2003; Nilsson et al. 2010), but many nonwetland plants primarily adapted to other dispersal modes (e.g., wind, bird) also move through water dispersal (Hampe 2004; Johansson et al. 1996; Nilsson et al. 2010; Saumel and Kowarik 2010). Streamflow not only transports seeds downstream, but also delivers them to different levels of the shoreline depending on flood stage and plant dispersal traits (Drezner et al. 2001; Merritt and Wohl 2002; Middleton 2000). Hydrochory also is a vector for riparian invasion by exotic plant species (Nilsson et al. 2010; Saumel and Kowarik 2010; Thomas et al. 2006; Truscott et al. 2006). Stream connectivity through hydrochory results in propagule pressure from large catchments so that downstream locations receive diverse species inputs, including invasive exotic species.

Invasive plants typically disperse downstream (e.g., Love et al. 2013; Nakayama et al. 2007), but many riparian invaders also disperse upstream, suggesting alternate, possibly anthropogenic, dispersal modes (Osawa et al. 2013). Anthropogenically altered landscapes commonly host many exotic plant species that invade riparian areas (Chytry et al. 2008; Osawa et al. 2013). For example, roadsides provide suitable habitat and roadways provide a dispersal corridor for many invasive plants (Christen and Matlack 2009; Flory and Clay 2009; Mortensen et al. 2009; Warren et al. 2011a). In turn, invasive plants spread from roads to adjacent riparian areas (Al-Chokhachy et al. 2013; Menuz and Kettenring 2013; Watterson and Jones 2006). 
The objective of this research was to evaluate the hydrological, geomorphological, and plant community characteristics that correspond with the distribution of six common invasive exotic riparian plant species in the eastern Great Lakes region. Investigating species invasions requires an assessment of both establishment and seed limitations (Eschtruth and Battles 2011), and little is known about the strength of each in promoting riparian invasion (Chytry et al. 2008). Whereas direct measurements, such as soil moisture and seed production, closely link with ecological dynamics, these measures often are impractical at a basinwide scale with "snapshot" survey data. Instead, proximate data, such as tree canopy cover as a proxy for reduced sunlight and temperature, are reasonable for applied assessment. We analyzed stream reach data collected as part of a basin-wide environmental assessment of the extensively urbanized upper Niagara River watershed in western New York State and tested whether invasive plant presence and richness appeared limited by habitat (establishment), availability (dispersal), or an interaction between the two. Given that propagule pressure and anthropogenic disturbance generally overwhelm habitat limitations in invasive species (Chytry et al. 2008; Von Holle and Simberloff 2005; Warren et al. 2012), we expected greater invasive species occurrence in riparian reaches close to roads with greater flooding and shallow bank slopes.

\section{Materials and Methods}

Study Sites. The study sites were located in the Niagara River Greenway, which is defined by municipal boundaries in Erie and Niagara counties in western New York State, USA (NRGC 2007) (Figure 1). The Greenway extends from the town of Porter, where the Niagara River enters Lake Ontario, through several municipalities located along the Niagara River, to the city of Buffalo in the southernmost portion of the Greenway. Greenway land use is mixed with the largest portion being classified as residential development $(31 \%)$, followed by agricultural $(17 \%)$ and vacant (17\%) (NRGC 2007). Our study sites included 348 reaches in 12 streams in the Greenway. A standard reach length of 61 $\mathrm{m}(200 \mathrm{ft})$ was used and reaches represented the combinations of vegetation, stream morphology, and hydrologic regime found throughout the Greenway. Five streams, Fish, Gill, Cayuga, Bergholtz, and Bull, were located in Niagara County. The remaining seven streams were located in Erie County and included the following creeks: Tonawanda, Ellicott, Two Mile, Woods, Gun, Big Six Mile, and Spicer.

Survey Methods. The Natural Resources Conservation Service (NRCS) Stream Visual Assessment Protocol (SVAP) (NRCS 1998, 2009) was used to collect stream condition data during the summer 2013 field season. The

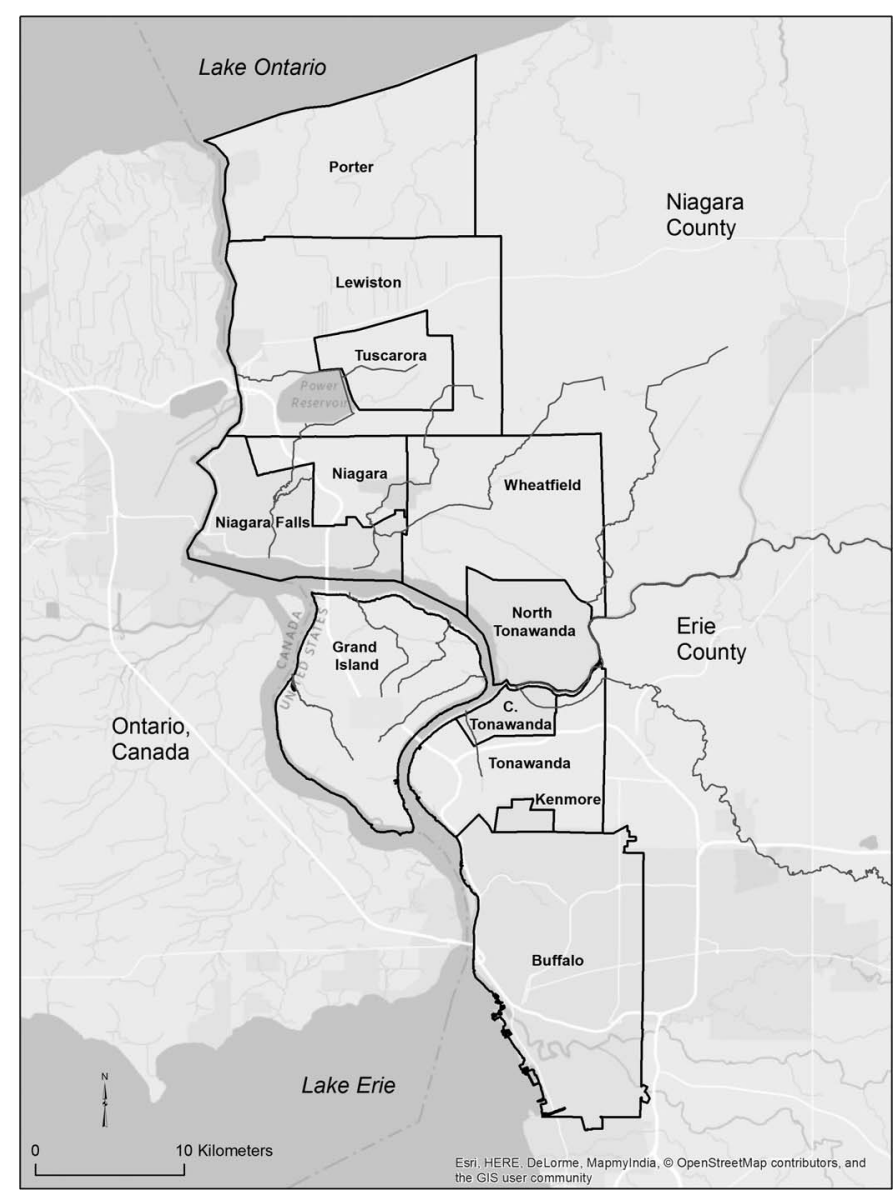

Figure 1. Map of the upper Niagara River watershed (western New York) with municipal boundaries and stream reaches.

SVAP is a qualitative multidisciplinary assessment used to perform rapid visual assessment of several elements of overall stream corridor conditions. The SVAP has been used to assess streams throughout the United States, and several studies demonstrate agreement between the SVAP and other qualitative assessment methods (Hughes et al. 2010; McQuaid and Norfleet 1999). Moreover, field crew training reduces observer bias and improves the precision and accuracy of qualitative assessment methods (Bjorkland et al. 2001; Hannaford et al. 1997; Ward et al. 2003). A trained three-person field crew scored SVAP elements in each stream reach, including channel condition, riparian zone, bank condition, water appearance, nutrient enrichment, pools and canopy cover. These elements were scored using an element description and scoring matrix (see NRCS 1998, 2009).

Study Species. The stream assessment database included the presence or absence of six invasive riparian plant species: Alliaria petiolata (Bieb.) Cavara \& Grande (garlic mustard, hereafter "Alliaria"), Lythrum salicaria L. (purple loosestrife, hereafter "Lythrum"), Phalaris arundinacea 
L. (reed canarygrass, hereafter "Phalaris"), Phragmites australis (Cav.) Trin. ex Steud. (common reed, hereafter "Phragmites"), Polygonum cuspidatum Sieb. \& Zucc. (Japanese knotweed, hereafter "Polygonum") and Rosa multiflora Thunb. ex Murr. (multiflora rose, hereafter "Rosa") (Table 1). All of the species are common invasive species in riparian areas in the region (PDEP 2004; USFSFEIS 2014), although Polygonum and Rosa were not common in our study plots.

Data Analysis. We examined covariation among invasive species presence in urban riparian areas using principal component analysis (PCA) using the "prncomp" method and "scale" option (standardizes all variables to unit length) in the $\mathrm{R}$ statistical package ( $\mathrm{R}$ Development Core Team 2015). For binary data, PCA places the descriptors in multidimensional space at the square root of their complements (Borcard et al. 2011). We excluded two species, Polygonum and Rosa, because there were not enough presence replicates for a meaningful analysis. These species were included, however, in community species richness and descriptive statistical analyses.

Given that species presence and richness generally increase with habitat area (Preston 1962), we included riparian extent (habitat area, $\mathrm{m}^{-2}$ ) to account for community saturation (i.e., larger habitat patches invariably contain greater species richness). We included flooding ( $\mathrm{m}$, channel depth at bank-full - channel depth at lowflow) as a predictor of hydrochorous seed movement (Boedeltje et al. 2004; Greet et al. 2012). Flooding also can create suitable plant recruitment conditions by eroding stream banks and depositing seeds at different distances from shore, and seed deposition decreases with bank steepness (Greet et al. 2011; Kronvang et al. 2009; Naiman and Decamps 1997; Soomers et al. 2010), so we included bank slope (m, channel depth at bank-full/channel width at bankfull) as a predictor of seed recruitment. Increased nutrients and roadways generally benefit invasive rather than native species (Menuz and Kettenring 2013), so we also included nutrient status (index) and riparian distance to road $(\mathrm{m})$. Because invasive plants generally are shadeintolerant (Bazzaz 1979), including most of our study species (Table 1), we also included riparian overstory canopy cover (index). The nutrient status and canopy cover indices were based on observer ratings at a scale of 1 to 10 . The nutrient status index included water color, algal growth, and aquatic plant density. The canopy cover index was based on categories of percentage of tree shading.

The stream field data were autocorrelated and unbalanced by stream, and the response variables were presence/absence and counts. We used a generalized linear mixed model (GLMM) approach to accommodate the study design with stream $(n=17)$ as a random effect and riparian extent, flooding, bank slope, nutrient status,

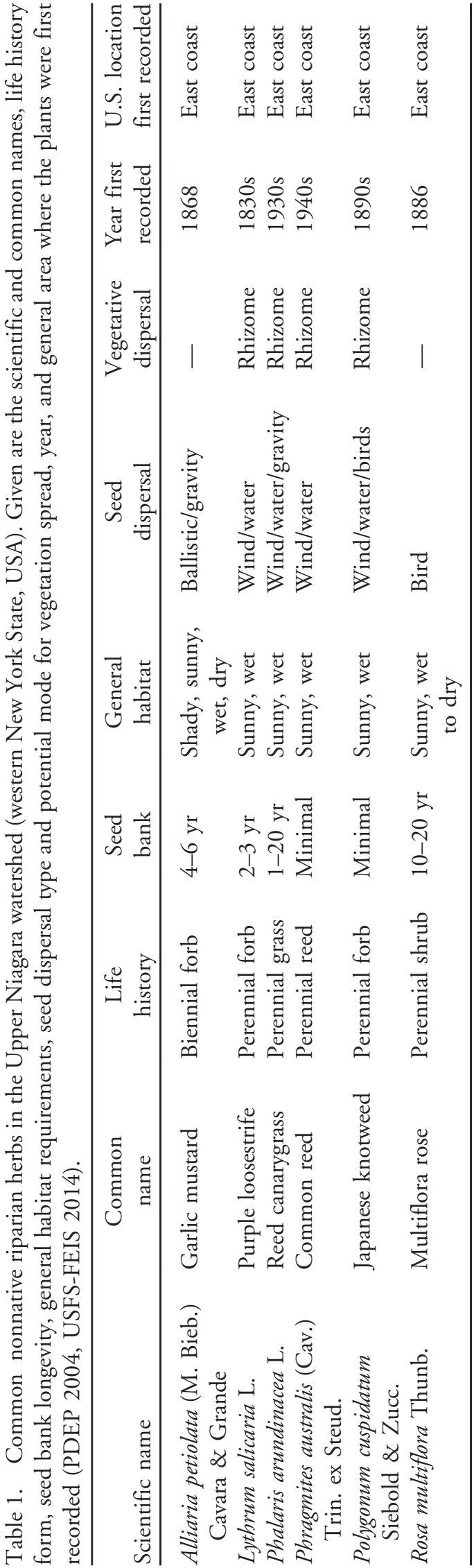

356 - Invasive Plant Science and Management 8, July-September 2015 
distance to road, and canopy cover as fixed effects. The GLMMs were evaluated using the "Ime4" package in the $\mathrm{R}$ statistical program. Invasive species presence/absence was modeled using a binomial error distribution and invasive species richness was modeled assuming a Poisson error distribution. We also modeled the individual presence of the four most common invasive species using GLMMs assuming binomial error distributions. Best-fit models were evaluated based on the inclusion or exclusion of the fixed effects and interaction terms, and model selection was based on the Akaike information criterion (AIC, $\Delta>2$ ). Potential collinearity between predictor variables was evaluated using the "car" package (Fox and Weisberg 2011). The variance inflation factors for the predictor variables in all models were $<1$, indicating they independently predict variance, and the binomial- and Poisson-distributed data were not overdispersed $(\phi<1.5)$. Interaction effects and second-order terms (to evaluate intermediate responses) were evaluated for all significant main effects.

\section{Results and Discussion}

Lythrum was the most common invasive plant found in our surveys $(62.5 \%$ of all stream reaches). Phragmites (50.0\%), Phalaris (31.9\%), and Alliaria (27.7\%) were less common, and Polygonum (6.9\%) and Rosa (2.8\%) were uncommon. Overall, $63.9 \%$ of the stream reaches were occupied by at least one of the invasive species. Plotting the four most common species on a biplot graph indicated that the first two principal components (PC1 and PC2) adequately explained correlation among plants $(68 \%$ of the variation) (Figure 2). Alliaria and Phalaris positively covaried along PC1 (43\% of the variance) whereas Lythrum and Phragmites negatively covaried along PC2 (25\% of the variance). The two plant groupings along PC1 and PC2 were orthogonal, indicating no relationship between them.

The best-fitting invasive presence model (based on AIC selection) retained all of the stream/riparian variables, but the slope values for flooding, nutrients, and distance to road did not differ significantly from zero. The likelihood of occurrence of invasive plant species increased significantly with riparian extent (coefficient [coef.] $=0.657$, SE $=0.210, \mathrm{z}=3.143, \mathrm{P}=0.002)$ and a significant canopy cover by slope interaction term (coef. $=2.729, \mathrm{SE}=$ $1.025, \mathrm{z}=2.663, \mathrm{P}=0.008)$ indicated that invasive species presence decreases significantly with canopy cover and increases with steeper banks, but neither has an effect where both are greatest (Figure 3). Similar to the presence model, the best-fitting invasive richness model also retained all of the stream/riparian variables, but none of the slope values differed from zero except canopy cover. Invasive species richness decreased significantly with canopy cover (coef. $=-0.096, \mathrm{SE}=0.028, \mathrm{z}=-3.459, \mathrm{P}=0.001$ ) (Figure 4).

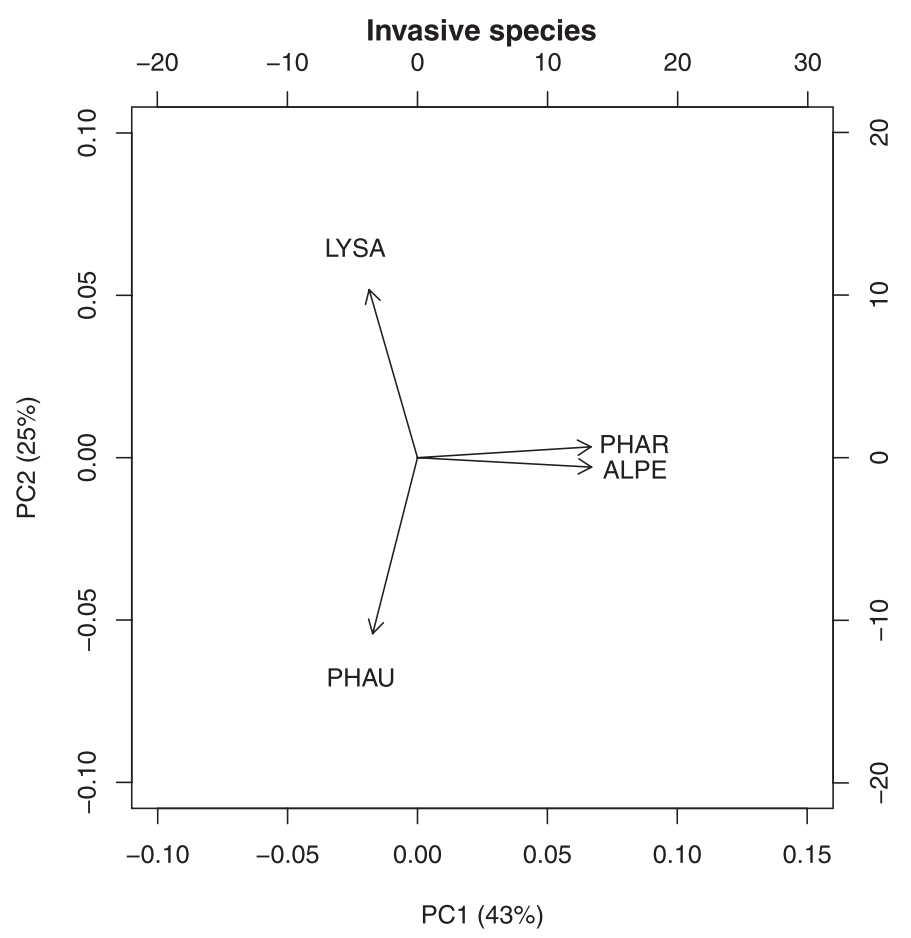

Figure 2. Principal component analysis of invasive riparian species. The biplot represents covariation among Alliaria petiolata (ALPE), Lythrum salicaria (LYSA), Phalaris arundinacea (PHAR), and Phragmites australis (PHAU). The length of the lines in the biplot indicates the degree of variation in a component (relatively longer lines indicate relatively higher variation). Lines that point in the same direction indicate a positive correlation between components; opposite directions indicate negative correlation and perpendicular lines indicate no relationship. The left and bottom axes give the standardized principal component values, and the right and top axes give the loadings. The biplot indicates that Alliaria often occurred with Phalaris whereas Lythrum and Phragmites generally did not occur together.

All stream/riparian variables best predicted Lythrum presence, but only the slope for increased riparian extent and decreased canopy cover differed significantly from zero (riparian extent, coef. $=0.699, \mathrm{SE}=0.240 \mathrm{z}=2.910, \mathrm{P}=$ 0.004; canopy cover, coef. $=-0.300, \mathrm{SE}=0.061, \mathrm{Z}=$ -4.996 , P <0.001). Only decreased canopy cover predicted the presence of Phragmites (coef. $=-0.235$, $\mathrm{SE}=0.106, \mathrm{z}=-2.215, \mathrm{P}=0.027)$. Distance to road, flooding, riparian extent, and canopy cover best predicted Phalaris presence, but none of the slope values differed significantly from zero. Only increased canopy cover predicted the presence of Alliaria (coef. $=0.345, \mathrm{SE}=$ $0.175, \mathrm{z}=1.977, \mathrm{P}=0.048$ ).

Invasive riparian plant communities appeared far more establishment- than seed-limited along the urban streams measured here. The invasive plants were more likely to 


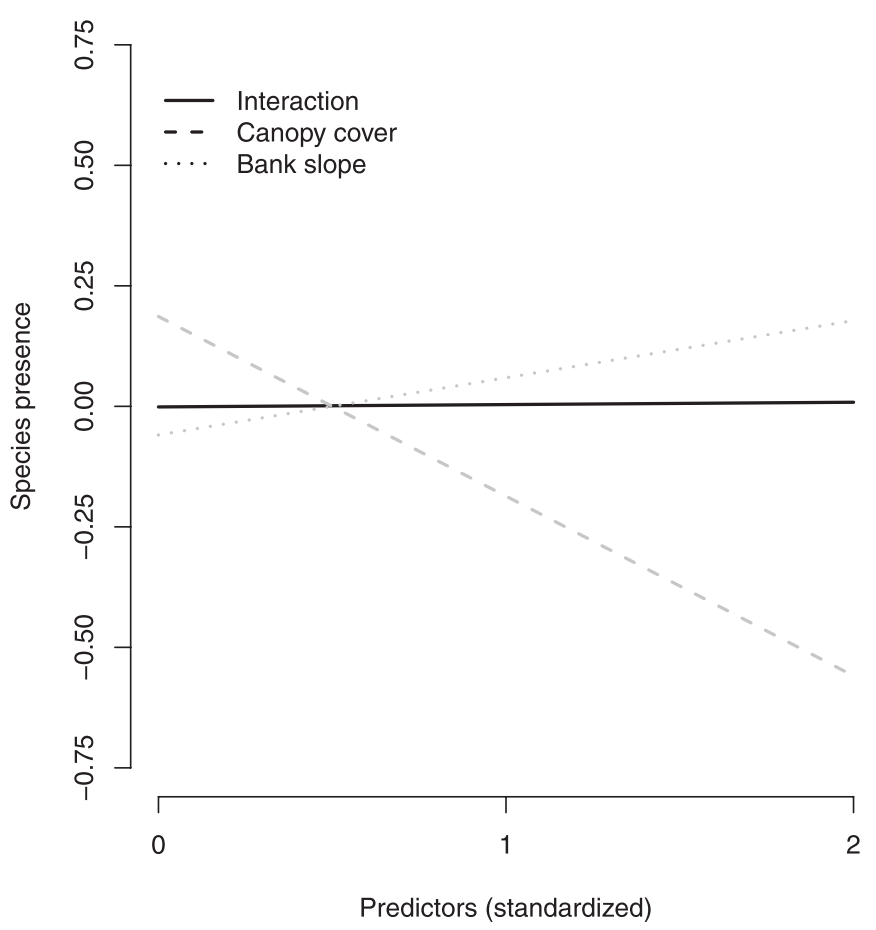

Figure 3. Continuous interaction plot of the effects of canopy cover and bank slope on riparian invasive species richness. The terms were recentered for graphing. The significant nonadditive effect of canopy cover and bank slope on invasive species richness indicates that fewer species occur with greater canopy coverage (dashed line), and more occur with steeper slopes (dotted line), but where canopy cover and slope steepness are greatest neither impacts invasive species richness (solid line).

occur in larger riparian areas, but increased tree canopy cover reduced their presence and community diversity along the streams. We found weaker evidence for dispersal limitations on the invasive plants.

The best-fit models for invasive species presence and richness retained all stream parameters. The strongest limitation on invasive species presence and richness was imposed by tree canopy cover-likely a proxy for light availability and temperature (Warren 2010a,b). Although some invasive species tolerate shade and invade beneath forest canopy (Martin et al. 2009), invasive species generally are shade-intolerant, including the species studied here (Dommanget et al. 2013; Marlor et al. 2014; Phillips-Mao et al. 2014). Lythrum and Phragmites presence decreased significantly in our plots with greater canopy coverage, but Alliaria presence actually increased. Alliaria appears a poor competitor where increased light promotes native species cover (Phillips-Mao et al. 2014) and unlike most invasive species, it may benefit from increased canopy cover. Interestingly, approximately $75 \%$ of riparian areas lack forest cover in the United States (Innis et al. 2000; Palmer et al. 2007; Wohl et al. 2007). Urban and riparian forest restoration are major management initiatives throughout the

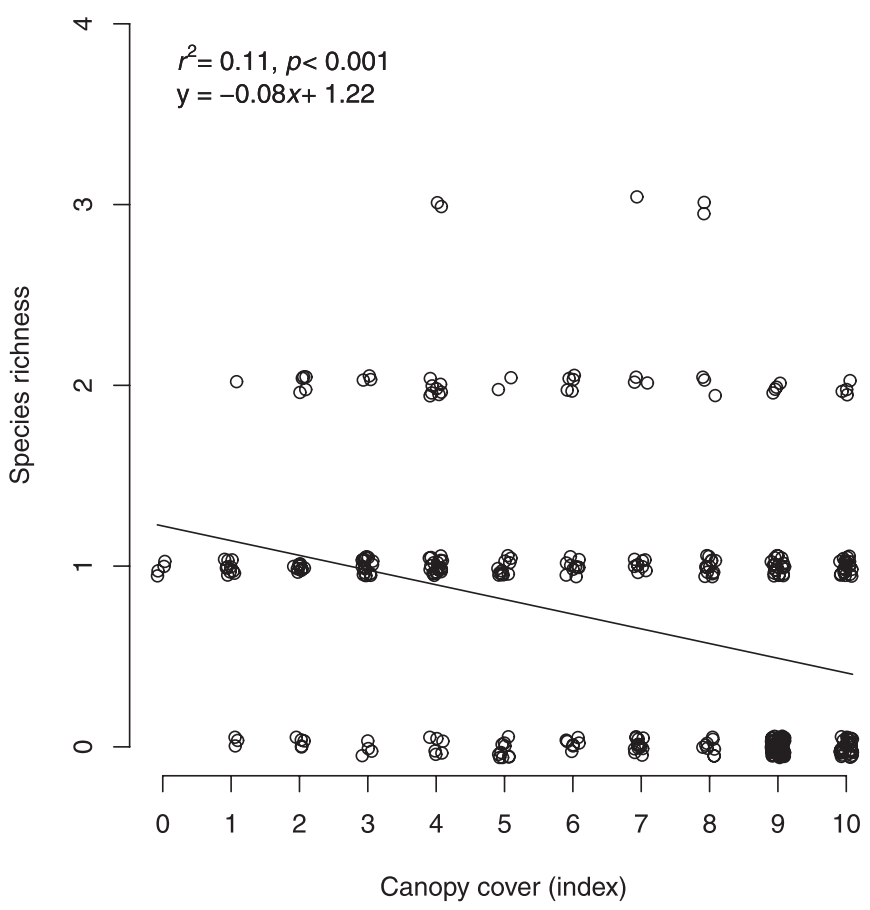

Figure 4. Scatterplot of invasive species richness as a function of tree canopy cover in urban riparian areas with fitted line and confidence interval. The points are slightly jittered to avoid overplotting. Invasive species richness decreased significantly $(\mathrm{P}<0.001)$ with greater canopy coverage, though the low goodness-of-fit $\left(R^{2}=0.11\right)$ of the residuals around the fitted line suggests that additional variables influenced richness.

United States (Oldfield et al. 2013; Sweeney and Czapka 2004). Benefits associated with these projects typically include improvements in water quality and wildlife habitat, erosion control, and recreation (Sweeney and Newbold 2014). The results presented here suggest that a reduction in the occurrence of invasive riparian plants also might be a potential benefit from urban riparian forest restoration.

We expected that riparian extent, flooding, and distance to road would indicate seed limitation, the latter two as seed vectors, but only riparian extent showed any influence on invasive presence, and invasive plants species were more likely to occur in larger riparian areas. Our data also indicated that suitable riparian habitat for invasive plants was delineated by canopy cover. The weak evidence for seed limitation may be due to the indirect proxies, but it is not necessarily surprising considering that all of the six riparian species recorded in the basin-wide assessment are longstanding invaders, all first recorded in the region 65 to $180 \mathrm{yr}$ before the assessment. Eschtruth and Battles (2011) found propagule pressure more limiting than habitat for three riparian invasive species, but all were recent invaders - the stage at which seed limitation would be expected. Moreover, the research was conducted in a natural 
area, which might be expected to contain fewer invasive species than the urban area where our data were collected. Finally, anthropogenic disturbance makes habitat more suitable for invasive species (Chytry et al. 2008), and urban stream systems are far more altered than those found in natural areas (Maskell et al. 2006; Paul and Meyer 2001; Pysek and Prach 1993).

The two species exhibiting the greatest tree canopy intolerance were Lythrum and Phragmites, but these also were the two species least likely to occur togethersuggesting that shade intolerance did not fully explain their distribution. Lythrum generally is an upland species, most common in roadside ditches, whereas Phragmites is more strongly associated with waterways, suggesting that a better measurement of soil moisture, hydrologic regime, or both may be required to explain why they did not coexist. Alliaria and Phalaris generally occurred together, but neither appeared terribly limited by the environmental variables measured here, except that Alliaria increased with tree canopy coverage. Both species are passively dispersed (Coops and Van der Velde 1995; Nuzzo 1991) and may have riparian distributions more defined by dispersal than habitat limitations.

An intriguing pattern found in our data is that steep bank slopes offset the negative effects of increased tree canopy cover on the presence of invasive riparian species. Given that streamflow variability increases seedling colonization on gradual, but not steep, sloping stream banks (van Leeuwen et al. 2014), the effect does not seem to be greater colonization. The negative impact of canopy cover very likely is due to shading, and steeper slopes change the angle of solar irradiation, increasing understory light availability and temperature (Cantlon 1953; Warren 2010b). This finding underscores the need for riparian restoration plans to acknowledge potentially complex interactions between resource availability, riparian plant community structure, and fluvial geomorphology.

We linked a qualitative stream assessment with riparian species invasion-essentially linking habitat structure and ecological patterning. Hence, we used proximate data collected as part of applied stream assessment to explain theoretical controls on plant distributions. Other studies also have demonstrated agreement between SVAP assessment methods and biota, such as macroinvertebrates (de Jesus-Crespo and Ramirez 2011; Hughes et al. 2010), but we did not find any literature linking SVAP with riparian vegetation. An excellent step in building upon our approach would be the collection of vegetation abundance data, either percentage of cover or biomass. Presence/ absence data limits our ability to assess the strength of establishment and seed limitations on the individual invasive plants. The binary analysis also makes it difficult to project trends and responses as the models linearize binary data in a statistically, but not intuitively, meaningful manner. Abundance data would not only allow inference about the strength of establishment and seed limitations on the invasive plants, but also give insight into the nonnative impacts on community and ecosystem processes.

Seed dispersal and the availability of suitable habitat determine species invasion. We found little evidence that long-established invasive species are dispersal-limited in urban riparian habitats, and habitat structure appeared the best predictor of invasive community richness. Still, although canopy coverage strongly limited the invasive communities, Alliaria increased with canopy; although the invasive community appeared more habitat- than dispersallimited, Alliaria and Phalaris appeared more dispersal- than habitat-limited. Lythrum and Phragmites did not co-occur, whereas Phalaris and Alliaria generally did. These results suggest that managing habitat structure may influence invasive communities as a whole, but managing individual invasive species may require specific interventions. Moreover, management activities that suppress a specific invasive species might promote another.

\section{Acknowledgments}

Jerome Krajna, Megan Klein, and Katherine Bauer assisted in the collection of field data and Mary Perrelli created the study area map. We thank two anonymous reviewers for helpful comments on the manuscript. This work was funded by Buffalo Niagara Riverkeeper.

\section{Literature Cited}

Al-Chokhachy R, Ray AM, Roper BB, Archer E (2013) Exotic plant colonization and occupancy within riparian areas of the interior Columbia River and Upper Missouri River basins, USA. Wetlands 33:409-420

Albrecht MA, McCarthy BC (2009) Seedling establishment shapes the distribution of shade-adapted forest herbs across a topographical moisture gradient. J Ecol 97:1037-1049

Andersson E, Nilsson C, Johansson ME (2000) Plant dispersal in a boreal river and its relation to diversity in riparian flora. J Biogeogr 27:1095-1106

Auble GT, Friedman JM, Scott ML (1994) Relating riparian vegetation to present and future streamflows. Ecol Appl 4:544-554

Baatrup-Pedersen A, Dalkvist D, Dybkjaer JB, Riis T, Larsen SE, Kronvang B (2013) Species recruitment following flooding, sediment deposition and seed addition in restored riparian areas. Restor Ecol 21:399-408

Bazzaz FA (1979) The physiological ecology of plant succession. Annu Rev Ecol Syst 10:351-371

Bjorkland R, Pringle CM, Newton B (2001) A stream visual assessment protocol (SVAP) for riparian landowners. Environ Monit Assess 68: 99-125

Boedeltje G, Bakker JP, Bekker RM, Van Groenendael JM, Soesbergen M (2003) Plant dispersal in a lowland stream in relation to occurrence and three specific life-history traits of the species in the species pool. J Ecol 91:855-866

Boedeltje G, Bakker JP, Brinke AT, Van Groenendael JM, Soesbergen M (2004) Dispersal phenology of hydrochorous plants in relation to 
discharge, seed release time and buoyancy of seeds: the flood pulse concept supported. J Ecol 92:786-796

Borcard D, Gillet F, Legendre P (2011) Numerical Ecology with R. New York: Springer

Bradford MA, Schumacher HB, Catovsky S, Eggers T, Newington JE, Tordoff GM (2007) Impacts of invasive plant species on riparian plant assemblages: interactions with elevated atmospheric carbon dioxide and nitrogen deposition. Oecologia 152:791-803

Cantlon JE (1953) Vegetation and microclimates on north and south slopes of Cushetunk Mountain, New Jersey. Ecol Monogr 23: 241-270

Casanova MT, Brock MA (2000) How do depth, duration and frequency of flooding influence the establishment of wetland plant communities? Plant Ecol 147:237-250

Christen DC, Matlack GR (2009) The habitat and conduit functions of roads in the spread of three invasive plant species. Biol Invasions 11: 453-465

Chytry M, Jarosik V, Pysek P, Hajek O, Knollova I, Tichy L, Danihelka J (2008) Separating habitat invasibility by alien plants from the actual level of invasion. Ecology 89:1541-1553

Clark CJ, Poulsen JR, Levey DJ, Osenberg CW (2007) Are plant populations seed limited? A critique and meta-analysis of seed addition experiments. Am Nat 170:128-142

Colautti RI, Grigorovich IA, MacIsaac HJ (2006) Propagule pressure: a null model for biological invasions. Biol Invasions 8:1023-1037

Coops H, Van der Velde G (1995) Seed dispersal, germination and seedling growth of six helophyte species in relation to water-level zonation. Freshw Biol 34:13-20

Cummins KW, Wilzbach MA, Gates DM, Perry JB, Taliaferro WB (1989) Shredders and riparian vegetation. Bioscience 39:24-30

Decamps H, Fortune M, Gazelle F, Pautou G (1988) Historical influence of man on the riparian dynamics of a fluvial landscape. Landsc Ecol 1:163-173

de Jesus-Crespo R, Ramirez A (2011) The use of a stream visual assessment protocol to determine ecosystem integrity in an urban watershed in Puerto Rico. Phys Chem Earth 36:560-566

Dommanget F, Spiegelberger T, Cavaille P, Evette A (2013) Light availability prevails over soil fertility and structure in the performance of Asian knotweeds on riverbanks: new management perspectives. Environ Manag 52:1453-1462

Drezner TD, Fall PL, Stromberg JC (2001) Plant distribution and dispersal mechanisms at the Hassayampa River Preserve, Arizona, USA. Glob Ecol Biogeogr 10:205-217

Elton CS (1958) The Ecology of Invasions of Animals and Plants. London: Methuen

Engstrom J, Nilsson C, Jansson R (2009) Effects of stream restoration on dispersal of plant propagules. J Appl Ecol 46:397-405

Eschtruth AK, Battles JJ (2009) Assessing the relative importance of disturbance, herbivory, diversity, and propagule pressure in exotic plant invasion. Ecol Monogr 79:265-280

Eschtruth AK, Battles JJ (2011) The importance of quantifying propagule pressure to understand invasion: an examination of riparian forest invasibility. Ecology 92:1314-1322

Flory SL, Clay K (2009) Effects of roads and forest successional age on experimental plant invasions. Biol Conserv 142:2531-2537

Fox J, Weisberg S (2011) An R Companion to Applied Regression. Thousand Oaks, CA: Sage

Greet J, Cousens RD, Webb JA (2012) Flow regulation affects temporal patterns of riverine plant seed dispersal: potential implications for plant recruitment. Freshw Biol 57:2568-2579

Greet J, Webb JA, Cousens RD (2011) The importance of seasonal flow timing for riparian vegetation dynamics: a systematic review using causal criteria analysis. Freshw Biol 56:1231-1247

Gregory SV, Swanson FJ, McKee WA, Cummins KW (1991) An ecosystem perspective of riparian zones. Bioscience 41:540-551
Groffman PM, Bain DJ, Band LE, Belt KT, Brush GS, Grove JM, Pouyat RV, Yesilonis IC, Zipperer WC (2003) Down by the riverside: urban riparian ecology. Front Ecol Environ 1:315-321

Grubb PJ (1977) Maintenance of species-richness in plant communitiesimportance of regeneration niche. Biol Rev 52:107-145

Gurnell AM, Thompson K, Goodson J, Moggridge H (2008) Propagule deposition along river margins: linking hydrology and ecology. J Ecol 96:553-565

Hampe A (2004) Extensive hydrochory uncouples spatiotemporal patterns of seed fall and seedling recruitment in a 'bird-dispersed' tree. J Ecol 92:797-807

Hannaford MJ, Barbour MT, Resh VH (1997) Training reduces observer variability in visual-based assessments of stream habitat. J North Am Benthol Soc 16:853-860

Hood WG, Naiman RJ (2000) Vulnerability of riparian zones to invasion by exotic vascular plants. Plant Ecol 148:105-114

Hughes RM, Herlihy AT, Kaufmann PR (2010) An evaluation of qualitative indexes of physical habitat applied to agricultural streams in ten U.S. states. J Am Water Resour Assoc 46:792-806

Innis SA, Naiman RJ, Elliott SR (2000) Indicators and assessment methods for measuring the ecological integrity of semi-aquatic terrestrial environments. Hydrobiologia 422/423:111-131

Jansson R, Zinko U, Merritt DM, Nilsson C (2005) Hydrochory increases riparian plant species richness: a comparison between a freeflowing and a regulated river. J Ecol 93:1094-1103

Johansson ME, Nilsson C, Nilsson E (1996) Do rivers function as corridors for plant dispersal? J Veg Sci 7:593-598

King JR, Tschinkel WR (2008) Experimental evidence that human impacts drive fire ant invasions and ecological change. Proc Natl Acad Sci U S A 105:20339-20343

Kowarik I, Saumel I (2008) Water dispersal as an additional pathway to invasions by the primarily wind-dispersed tree Ailanthus altissima. Plant Ecol 198:241-252

Kronvang B, Hoffman CC, Droge R (2009) Sediment deposition and net phosphorus retention in a hydraulically restored lowland river floodplain in Denmark: combining field and laboratory experiments. Mar Freshw Res 60:638-646

Lecerf A, Patfield D, Boiche A, Riipinen MP, Chauvet E, Dobson M (2007) Stream ecosystems respond to riparian invasion by Japanese knotweed (Fallopia japonica). Can J Fish Aquat Sci 64:1273-1283

Leyer I (2006) Dispersal, diversity and distribution patterns in pioneer vegetation: the role of river-floodplain connectivity. J Veg Sci 17: 407-416

Lockwood JL, Cassey P, Blackburn T (2005) The role of propagule pressure in explaining species invasions. Trends Ecol Evol 20: 223-228

Love HM, Maggs CA, Murray TE, Provan J (2013) Genetic evidence for predominately hydrochoric gene flow in the invasive riparian plant Impatiens glandulifera (Himalayan balsam). Ann Bot 112:1743-1750

Marlor KM, Webster CR, Chimner RA (2014) Disturbance and wetland type alter reed canarygrass cover in northern Michigan. Invasive Plant Sci Manag 7:121-131

Martin PH, Canham CD, Marks PL (2009) Why forests appear resistant to exotic plant invasions: intentional introductions, stand dynamics, and the role of shade tolerance. Front Ecol Environ 7: 142-149

Maskell LC, Bullock JM, Smart SM, Thompson K, Hulme PE (2006) The distribution and habitat associations of non-native plant species in urban riparian habitats. J Veg Sci 17:499-508

McQuaid BF, Norfleet L (1999) Assessment of two Carolina watersheds using land and stream quality indices. J Soil Water Conserv 54: 657-665

Menuz DR, Kettenring KM (2013) The importance of roads, nutrients, and climate for invasive plant establishment in riparian areas in the northwestern United States. Biol Invasions 15:1601-1612 
Merritt DM, Nilsson C, Jansson R (2010) Consequences of propagule dispersal and river fragmentation for riparian plant community diversity and turnover. Ecol Monogr 80:609-626

Merritt DM, Wohl EE (2002) Processes governing hydrochory along rivers: hydraulics, hydrology, and dispersal phenology. Ecol Appl 12: 1071-1087

Merritt DM, Wohl EE (2006) Plant dispersal along rivers fragmented by dams. River Res Appl 22:1-26

Middleton BA (2000) Hydrochory, seed banks, and regeneration dynamics across landscape boundaries in a forested wetland. Plant Ecol 146:169-184

Mortensen DA, Rauschert ESJ, Nord AN, Jones BP (2009) Forest roads facilitate the spread of invasive plants. Invasive Plant Sci Manag 2: 191-199

Naiman RJ, Decamps H (1997) The ecology of interfaces: riparian zone. Annu Rev Ecol Syst 28:621-658

Naiman RJ, Decamps H, Pollock M (1993) The role of riparian corridors in maintaining regional biodiversity. Ecol Appl 3:209-212

Nakayama N, Nishihiro J, Kayaba Y, Muranaka T, Washitani I (2007) Seed deposition of Eragrostis curvula, an invasive alien plant, on a river floodplain. Ecol Res 22:696-701

Nilsson C, Brown RL, Jansson R, Merritt DM (2010) The role of hydrochory in structuring riparian and wetland vegetation. Biol Rev 85:837-858

Nilsson C, Ekblad A, Gardfell M, Carlberg B (1991) Long-term effects of river regulation on river margin vegetation. J Appl Ecol 28:963-987

[NRCS] Natural Resources Conservation Service (1998) Stream Visual Assessment Protocol. Natural Resources Conservation Service Technical Note 99-1. $42 \mathrm{p}$

[NRCS] Natural Resources Conservation Service (2009) Stream Visual Assessment Protocol Version 2. National Biology Handbook, Subpart B-Conservation Planning. Natural Resources Conservation Service. $75 \mathrm{p}$

[NRGC] Niagara River Greenway Commission (2007) Niagara River Greenway Plan and Final Environmental Impact Statement. Niagara River Greenway Commission. 243 p

Nuzzo VA (1991) Experimental control of garlic mustard [Alliaria petiolata (Bieb.) Cavara \& Grande] in northern Illinois using fire, herbicide and cutting. Nat Areas J 11:158-167

Oldfield EE, Warren RJ II, Felson AJ, Bradford MA (2013) Challenges and future directions in urban afforestation. J Appl Ecol 50: $1169-1177$

Osawa T, Mitsuhashi H, Niwa H (2013) Many alien invasive plants disperse against the direction of stream flow in riparian areas. Ecol Complex 15:26-32

Palmer M, Allen JD, Meyer J, Bernhardt ES (2007) River restoration in the twenty-first century: data and experiential knowledge to inform future efforts. Restor Ecol 15:472-481

Parendes LA, Jones JA (2000) Role of light availability and dispersal in exotic plant invasion along roads and streams in the H.J. Andrews Experimental Forest, Oregon. Conserv Biol 14:64-75

Paul MJ, Meyer JL (2001) Streams in the urban landscape. Annu Rev Ecol Syst 32:333-365

[PDEP] Pennsylvania Department of Environmental Protection (2004) Pennsylvania Field Guide-Common Invasive Plants in Riparian Areas. Pennsylvania Department of Environmental Protection. 29

Phillips-Mao L, Larson DL, Jordan NR (2014) Effects of native herbs and light on garlic mustard (Alliaria petiolata) invasion. Invasive Plant Sci Manag 7:257-268

Poulsen JR, Osenberg CW, Clark CJ, Levey DJ, Bolker BM (2007) Plants as reef fish: fitting the functional form of seedling recruitment. Am Nat 170:167-183

Preston FW (1962) The canonical distribution of commonness and rarity: part I. Ecology 43:185-215
Pulliam HR (1988) Sources, sinks, and population regulation. Am Nat 132:652-661

Pysek P, Prach K (1993) Plant invasions and the role of riparian habitats: a comparison of four species alien to central Europe. J Biogeogr 20:413-420

Rood SB, Heinz-Milne S (1989) Abrupt riparian forest decline following river damning in southern Alberta. Can J Bot 67: 1744-1749

Sabo JL, Sponseller R, Dixon M, Gade K, Harms T, Heffernan J, Jani A, Katz G, Soykan C, Watts J, Welter J (2005) Riparian zones increase regional species richness by harboring different, not more, species. Ecology 86:56-62

Saumel I, Kowarik I (2010) Urban rivers as dispersal corridors for primarily wind-dispersed invasive tree species. Landsc Urban Plann 94:244-249

Soomers H, Winkel DN, Du Y, Wassen MJ (2010) The dispersal and deposition of hydrochorous plant seeds in drainage ditches. Freshw Biol 55:2032-2046

Sweeney BW, Czapka SJ (2004) Riparian forest restoration: why each site needs an ecological prescription. For Ecol Manag 192:361-373

Sweeney BW, Newbold JD (2014) Streamside forest buffer width needed to protect stream water quality, habitat and organisms: a literature review. J Am Water Resour Assoc 50:560-584

Tanentzap AJ, Bazely DR (2009) Propagule pressure and resource availability determine plant community invasibility in a temperate forest understorey. Oikos 118:300-308

Thomas JR, Middleton B, Gibson DJ (2006) A landscape perspective of the stream corridor invasion and habitat characteristics of an exotic (Dioscorea oppositifolia) in a pristine watershed in Illinois. Biol Invasions 8:1103-1113

Tickner DP, Angold PG, Gurnell AM, Mountford JO (2001) Riparian plant invasions: hydrogeomorphological control and ecological impacts. Prog Phys Geogr 25:22-52

Truscott AM, Soulsby C, Palmer SCF, Newell L, Hulme PE (2006) The dispersal characteristics of the invasive plant Mimulus guttatus and the ecological significance of increased occurrence of high-flow events. J Ecol 94:1080-1091

[USFS-FEIS] U.S. Forest Service Fire Effects Information System (2014) Fire Effects Information System. Washington, DC: United States Forest Service.

van Leeuwen CHA, Sarneel JM, van Paassen J, Rip WJ, Bakker ES (2014) Hydrology, shore morphology and species traits affect seed dispersal, germination and community assembly in shoreline plant communities. J Ecol 102:998-1007

Vogt K, Rasran L, Jensen K (2006) Seed deposition in drift lines during an extreme flooding event. Evidence for hydrochorous dispersal? Basic Appl Ecol 7:422-432

Von Holle B, Simberloff D (2005) Ecological resistance to biological invasion overwhelmed by propagule pressure. Ecology 86: 3212-3218

Walsh CJ, Roy AH, Feminella JW, Cottingham PD, Groffman PM, Morgan RP III (2014) The urban stream syndrome: current knowledge and the search for a cure. J North Am Benthol Soc 24: 706-723

Ward TA, Tate KW, Atwill ER, Lile DF, Lancaster DL, McDougald N, Barry S, Ingramm RS, George HA, Jensen W, Frost WE, Phillips R, Markegard GG, Larson S (2003) A comparison of three visual assessments for riparian and stream health. J Soil Water Conserv 58: $85-88$

Warren RJ II (2010a) A test of temperature estimation from solar irradiation and a simple statistical method to integrate elevation into prediction models. Castanea 75:67-77

Warren RJ II (2010b) An experimental test of well-described vegetation patterns across slope aspects using woodland herb transplants and manipulated abiotic drivers. New Phytol 185:1038-1049 
Warren RJ II, Bahn V, Bradford MA (2012) The interaction between propagule pressure, habitat suitability and density-dependent reproduction in species invasion. Oikos 121:874-881

Warren RJ II, Bahn V, Kramer T, Tang Y, Bradford MA (2011a) Performance and reproduction of an exotic invader across temperate forest gradients. Ecosphere 2:1-19

Warren RJ II, Bradford MA (2011) The shape of things to come: woodland herb niche contraction begins during recruitment in mesic forest microhabitat. Proc R Soc B Biol Sci 278:1390-1398

Warren RJ II, Ursell T, Keiser AD, Bradford MA (2013) Habitat, dispersal and propagule pressure control exotic plant infilling within an invaded range. Ecosphere 4:26

Warren RJ II, Wright JP, Bradford MA (2011b) The putative niche requirements and landscape dynamics of Microstegium vimineum - an invasive Asian grass. Biol Invasions 13:471-483
Watterson NA, Jones JA (2006) Flood and debris flow interactions with roads promote the invasion of exotic plants along steep mountain streams, western Oregon. Geomorphology 78: 107-123

Wohl EM, Palmer MA, Kondolf JM (2007) River Management in the United States. Pages 174-195 in Brierley GJ, Fryirs KA, eds. River Futures. Washington, DC: Island

Yang J, Dilts TE, Condon LA, Turner PL, Wiesberg PJ (2011) Longitudinal- and transverse-scale environmental influences on riparian vegetation across multiple levels of ecological organization. Landsc Ecol 26:381-395

Received December 17, 2014, and approved May 27, 2015.

Associate Editor for this paper: Jacob N. Barney, Virginia Tech. 